\title{
An Assessment of the Determinants of Productivity in the Electricity Industry in Nigeria
}

\author{
Olatunji, Olabode David. (PhD)
}

Department of Business Administration, Adekunle Ajasin University, Akungba-Akoko, Ondo State, Nigeria

Doi:10.19044/esj.2018.v14n19p256 URL:http://dx.doi.org/10.19044/esj.2018.v14n19p256

\begin{abstract}
The study examined the productivity in the electricity industry in Nigeria. The aim of the study was to ascertain the determinants of productivity in the electricity sector. The research design adopted for the study was a longitudinal study of productivity in the electricity industry in Nigeria. The study considered time series data for a 20 year period from 1996 to 2015. Data on study variables were obtained from Central Bank of Nigeria $(\mathrm{CBN})$ statistical bulletins, National Bureau of Statistics (NBS) annual publications, and the websites of both Transparency International (TI) and Energy Information Administration (EIA). Based on the study objectives, the fully modified ordinary least square (FM-OLS) technique was used to estimate the multiple regressions between productivity and the explanatory variables. Data analyses were carried out using the software application of E- View 9.0.

Results from the study showed that the total factor productivity which is an indication of efficiency in the electricity sector was 0.29 . This is low when compared with international best practice of 0.80 . Also, results from the study revealed that funding, weather condition, vandalism and labour supply have significant effect on productivity of the electricity industry in Nigeria. However, tariff structure and corruption were not statistically significant in the prediction of productivity in the electricity industry. The study recommended that increased budgetary allocations should be made available to the electricity industry to provide the needed improvements in the sector.
\end{abstract}

Keywords: Productivity, Electricity Industry, Performance, Nigeria

\section{INTRODUCTION}

Electricity is an important service in an economy with unique characteristics; it is an input in the production of most goods and services, and it is also an essential final good, consumed by households and more importantly it cannot be stored (Steiner, 2001). Global demand for energy is 
rising fast, and demand for electricity is rising even faster. According to a World Bank study in 2009, electricity consumption has been on a steady increase all over the world and the study concludes that unless changes are made in policy formulation, global electricity consumption will be close to 30,000 terawatt hours a year by 2020 (ESMAP, 2009). This figure according to Momani (2013) is more than twice the amount used in year 2000. This, thus, highlights the importance of electricity as a factor in the production process and also as an important service desired by every consumer.

The power sector in Nigeria has been be-devilled by a number of challenges, one of which is the epileptic nature of its supply (Zubair \& Olanrewaju, 2014). Also, according to Obi and Uzodigwe (2016), the electricity industry in Nigeria has continued to underperform, with a system plagued by high levels of unreliability, constant load-shedding, inadequate investment in new capacity to meet up with increasing consumers demand, and energy losses due largely to vandalism and gross inefficiency of key officials. Numerous reasons have been adduced for this unpleasant state of the power sector, but Sule (2010) asserts that the near absence of credible maintenance strategy was largely responsible for this state of affairs.

Obioma and Obioma (2012) in their study of productivity in the Nigeria power sector note that the crisis in the electricity industry has resulted into imbalances in the nation's quest for rapid socio economic development. They further observe that government in an attempt to solve the problem and thus improve productivity in the sector, resorted to the setting up of new power plants through the independent power programme (IPP). However, as observed by Folorunso and Olowu (2014), this is just a short run solution to the power crisis as the maintenance issues that made the older plants to underperform will no sooner than later also affect the new ones and they also go down.

Researches in productivity measurement abound in the literature. But most of these studies were conducted in the manufacturing industry (Ali, Ogunwolu and Oke, 2009; Eti, Ogaji \& Probert, 2004; Kumar, Varambally, \& Rodrigues, 2012; Muchiri, Pintelon, Martinb, \& De Meyer, 2010; Nenadál, 2008; and Tsang, 2000). In the electricity industry, only few studies on productivity measurement are conducted and they are mainly at the firm level (Ellison, 2013 and Barzel, 1963). Even in this instance, the analysis is concentrated on the distribution networks. The productivity measurement researches that were conducted in the generation segments of the electricity industry were mainly benchmarking analysis with the use of non-parametric tools of analysis such as Data Envelopment Analysis (DEA) (Jamsb, Pollit \& Newberry, 2004; and Obioma \& Obioma, 2012). In Nigeria, researches in the electricity industry follow the same pattern like the rest of the world with most of the studies being done on measuring the electricity efficiency of specific 
generation stations across the country (Madueme, 2002; Sule, 2010; and Isaac \& Obodeh, 2011). Even the few studies that tend to examine the Nigeria's electricity sector productivity only attempted benchmarking analysis of the operations of the sector with those of few other countries in the world (Babalola, 1999; Barros, Ibiwoye \& Managi, 2011 and Obioma \& Obioma, 2012). Thus, none of these researches have attempted to study the determinants of productivity in electricity generation at industry level. However, as pointed out by Tsang (1999), productivity measurement needs to be done holistically in an industry so that the factors affecting performance could be identified and analysed, and thus be used as the thrust of policy formulation and implementation for the overall improvement of the sector.

Based on the above scenarios, the questions we address in this study are as follow: (i) what are the determinants of productivity in the electricity industry in Nigeria? (ii) What is the level of efficiency in the electricity industry in Nigeria since the privatisation of the sector? Hence the objectives of the study are to investigate the determinants of productivity in the electricity industry in Nigeria. The rest of the paper are organised as follow: The literature review, methodology of the study, data presentation, analysis and interpretation, summary and conclusion.

\section{LITERATURE REVIEW}

\subsection{Productivity measurement}

Productivity is generally regarded as a ratio of a volume measure of output to a volume measure of input used in the production process. The concept of productivity has assumed different meanings over the years. Mo (1981) opines that the meaning of productivity depends on the definitions accorded to output and inputs, the methodology by which the concept is statistically operationalized and the manner in which outputs are related to inputs. Thus, we have such terms as labour productivity, capital productivity, total factor productivity and multi-factor productivity. Maheshwari, Manwani and Banerjee (2014) note that productivity can be conceptualised in terms of production function, financial ratio, economic utility and surrogate models. Thus, defining productivity can be very complex as it has roots in technology, engineering and management. Our concern in this paper is with the management aspect. In this connection, productivity is a measure that is used to evaluate the aggregate performance of a business unit over a period of time. The objectives of productivity measurement according to Radovilsky and Gotcher (1992) include: improving technical changes, promoting efficiency in production system and benchmarking production process. However, Gupta and Dey (2010) are of the opinion that the type of productivity measure required will depend on the level of analysis and the data available. Sink (1983) posits that we can use five critical indices to measure the productivity 
of a firm. These indices include: effectiveness, efficiency, quality, productive capacity, quality of work life, innovations, and profitability. Thus, productivity is an important factor for measuring the success of any business organisation. Hannula (2002) stresses the fact that organisations which are able to improve on their productivity will be profitable and also be competitive in their business domain. Therefore, there is the need to determine the productivity of an organisation through the use of appropriate productivity measurements.

In the electricity sector, a number of studies have been conducted regarding the productivity measurements of the core activities of generation transmission and distribution. Notable works in this category include that of Nerlove (1963), Barzel (1963), and Chrlstensen and Greene (1976). Generally, the measurement of productivity often involves finding a ratio between output and a number of inputs. However, in the electricity generation sector, productivity measurement is more complex than this simple method. In this sense, output in the power sector could mean load factor, capacity factor, availability factor, and energy losses (Barzel, 1963). Also, unlike the traditional productivity measurement that viewed inputs only in terms of labour and capital, productivity measurement in the power industry considers inputs as operational variables that are directly affecting the performance of the firm. These include the fuel and labour costs. However, Wang, Xie, Shang and $\mathrm{Li} \mathrm{(2013)}$ posit that the majority of scholars in the literature find that besides fuel and labour costs, external factors such as policy changes and economic development, also influence the productivity of the power industry. Notable among these scholars include Yu, Jamasb and Pollit (2009), Lam and Shiu (2001) and Abbott (2006). For example Yu et al. (2009) discuss the weather effects on performance of United Kingdom electricity utilities and find a positive relationship between the two variables. Lam and Shiu (2001) employ Tobit analysis in the second stage to regress the traditional efficiency scores obtained in the first stage against a set of selected uncontrollable variables. Abbott (2006) analysed productivity changes in the Australian electricity supply industry and evaluated the effects of environmental factors on the productivity of the sector.

\subsection{Determinants of Productivity in the electricity sector}

Although the choice of input and output variables is an important issue, there is no clear consensus in the literature about the variables that should be included to describe the factors affecting the productivity of generation, transmission and distribution companies in the electricity industry. Jamasb and Pollitt (2001) show a wide range of variables that have been used in benchmarking analysis of electric utilities. They find that the most commonly used inputs in studies of electric utilities are utility prices, funding of the 
sector, weather condition and human factors. In the case of Nigeria. Ubi, Effiom, Okon and Oduneka, (2012) revealed some factors that are peculiar to the country. These include vandals' activities, corruption and poor energy mix. Regarding the outputs, the most included variables are the load factor, operating capacity and operating ratio (ESMAP, 2009). Some of these factors are discussed below:

Tariff Structure (Price): The process of determining the price of electricity to consumers has far-reaching impacts throughout the electricity sector. It not only affects the financial viability of the sector and the quality and affordability of consumer services, but it raises concerns about the long term sustainability and maintenance of critical assets of the industry (Dixit, Wood, Jairaj \& Martin, 2014). In Nigeria, the price of electricity is fixed by the regulatory authority which is usually below the market price for it. Tallapragada (2009) in his study on the challenges of electricity supply in Nigeria notes that the tariff for the Nigerian electricity market is one of the lowest in the world. Babalola (1999) in a study on the relationship between electricity tariffs and maintenance cost notes that low price of electricity would fuel increase in the demand for electricity consumption by the consumers thereby increasing cost of maintaining the power network.

Hypothesis 1: Tariff structure does not significantly influence productivity in the electricity industry in Nigeria.

Funding of the Sector. Adequate funding of the power sector is required for the electricity industry to function effectively in any country (Sule, 2010). In Nigeria and until recently, government has been the main provider of the funds to enhance the productivity of the power industry. Babalola (1999) identifies funding as a core problem in the development of efficient maintenance system in the electricity industry in Nigeria. He further notes that the efficient operation of a power system is capital intensive. Thus, the ability of the operators to procure adequate quantities of spare parts and equipment as well as recruit competent manpower for the maintenance, overhaul and rehabilitation has a direct relationship with the financial resources available to the sector power sector.

Hypothesis 2: Funding does not significantly influence productivity in the electricity industry in Nigeria.

\section{Corruption}

Corruption has tended to manifest itself in many spheres of human endeavour, particularly in the area of infrastructural development. Often times, funds meant for the provision of critical equipment in aid of social infrastructure are diverted through corruption. Tanxi and Davoodi (1998) posit that the effect of corruption on infrastructural development in a country is to reduce public spending on education, operation and maintenance, and health. 
In the electricity industry especially in Nigeria, corruption has largely impeded the growth of that sector in the sense that money meant to procure necessary equipment to stabilise the system and guarantee regular power supply are often misappropriated (Olugbenga, Jumach \& Phillips, 2013). Gulati and Rao (2006) in their study found a relationship between corruption and the management of critical infrastructure in the electricity sector in most developing countries.

Hypothesis 3: The level of corruption does not have significant effect on productivity in the electricity sector in Nigeria.

Weather Condition: According to Sule (2010), one of the most decisive uncontrollable factors in electricity generation, transmission and distribution is the weather conditions of the area in which the companies operate. A large number of the electricity generation companies in Nigeria are hydro power stations. Specifically, these include the power stations at Kainji, Shiroro, and Jebba. The unpredictability of the weather condition in term of rainfall in Nigeria has tended to impact negatively on the ability of the generation companies to embark on their schedule maintenance, thus resulting in long period of downturn for critical equipment. Momani (2013) in his study of electricity demand in Jordan found a positive relationship between productivity $(\mathrm{P})$ and climatic conditions such as rainfall and ambient temperature.

Hypothesis 4: Weather condition does not significantly influence productivity in the electricity industry in Nigeria.

Vandals' activities: Vandalism of critical assets in power infrastructure has tended to impact negatively on electricity supply in developing countries over the years. Ali, Kamaruzzaman, Sulaiman and Peng (2010) identify vandalism as one of the factors affecting the productivity and maintenance cost of critical infrastructure in Malaysia. Dzansi, Rambe and Mathe (2014) study the involvement of employees in cable theft and vandalism in electric utilities in South Africa and concluded that the immediate effect of acts of vandalism on power infrastructure is to increase the cost of maintenance and reduce the productivity of this important sector. In Nigeria, the restiveness in the Niger Delta area of the country where majority of gas infrastructure needed to fire the generation plants are located has impacted negatively on the productivity of most of the electricity generation companies (Ibiyemi, 2006; Okoro \& Chikuni, 2007 and Adenikinju, 2008).

Hypothesis 5: Vandalism does not significantly affect productivity in the electricity in Nigeria. 


\section{Skilled Manpower}

The electricity sector is a technologically intensive industry where the appropriate type of labour must be available to operate some of the equipment being used. As noted by Lave, Ashworth and Gellings (2007: 3) "the intricate relationships between investment, planning, engineering, construction, and maintenance functions in the electricity industry require employees who are not only highly trained and knowledgeable but also constantly aware of the needs of retail consumers, regulators, suppliers, and investors". Thus in a study by Muchiri et al (2010), a positive relationship was found between labour and productivity in the electricity industry of Belgium.

.Hypothesis 6: Availability of manpower does not significantly affect productivity in the electricity industry in Nigeria.

\subsection{Profile of the electricity industry in Nigeria}

The Nigerian electricity industry has long years of chequered history. According to Sule (2010), the first attempt to provide electricity in Nigeria was by the colonialist in 1896 with the construction of $30 \mathrm{KW}$ station in Ijora to provide power at Ikoyi where the colonialists were residing. Ordinance number 15 passed by the colonial government in 1950 marked the beginning of national electricity body in Nigeria with the establishment of Electricity Corporation of Nigeria (ECN) (Uzoh, \& Duru, (2014). But with decree 24 of 1972, the ECN and National Dam Authority (NDA) were merged to form what was known as National Electricity Power Authority (NEPA) (Sule, 2010).

However, according to Ahmed (2008), there was no significant investment in expanding and maintaining the country's electricity generating capacity for about 20 years prior to 1999 resulting in a very low generation of electricity when compared to installed capacity. For example, Ahmed (2008) cites the instance of where the annual investment in the Nigerian power sector between 1990 and 1999 was estimated at about US13\$, a reduction of about $20 \%$ of the amount spent each year in the previous decade. Okoro and Chikinu (2007) state that because of the inability of NEPA to meet the basic energy needs of Nigerians, another body was set up in 2005 known as Power Holding Corporation of Nigeria (PHCN) with the basic objective of fashioning out a new way to providing constant electricity to Nigerians. However, Okoro (2014) states that even with the establishment of the PHCN the electricity situation in Nigeria did not improve for better which thus prompted the government to grant licences to independent power producers to complement the efforts of the PHCN.

In accordance with the Electricity Power Sector Reform Act 2005, the privatization of PHCN was finally established in 2013. PHCN was subsequently unbundled into a transmission company (TCN), six generating companies (Gencos) and eleven distribution companies (Discos). The Federal 
Government retains the ownership of the transmission assets and Manitoba Hydro International (Canada) is charged with the responsibility of revamping TCN to achieve and provide stable transmission of power without system failure. Currently, the transmission capacity of the Nigerian Electricity Transmission system is made up of about $5,523.8 \mathrm{~km}$ of $330 \mathrm{KV}$ lines and $6,801.49 \mathrm{~km}$ of $132 \mathrm{KV}$ lines (Joseph, 2014). However, the generation and distribution sectors were fully privatised and owned by private individuals.

\section{METHODOLOGY}

The research design was a longitudinal study of Productivity in the Electricity Industry in Nigeria. The study considered time series data for 20 years period from 1996 to 2015 . The choice of the period was informed by the desire to take a fairly long - term view of influencing factors of Productivity of Electricity industry in Nigeria. The choice of 1996 as the starting period for the study was informed by the fact that data for measuring one of the important explanatory variables in the model (corruption) was not available prior to that date. Also, it was in this period that the Nigeria's electricity industry witnessed increased efforts for greater efficiency through the unbundling of the PHCN and the subsequent sales of the DISCO's and GENCO's to private investors. The electricity industry in Nigeria is comprised of generation, transmission and distribution segments. However, because of availability of data, the study focused on the generation segment of the industry in the measurement of productivity.

\subsection{Model Specification}

The ordinary least square model based on fully modified least square FM-OLS was utilised to estimate the linear relationship between maintenance productivity and its predicting variables. Thus, following Betancourt and Edwards (1987), the mathematical model formulation of productivity can be generally expressed as follows based on time series data. Using the Cobb Douglas Production Function as the starting point:

$$
Y=A L^{\beta} K^{\alpha}
$$

Where $\mathrm{Y}=$ Total production (output)

$$
\begin{aligned}
& \mathrm{L}=\mathrm{Labour} \text { input } \\
& \qquad \begin{array}{l}
\mathrm{K} \\
\mathrm{A}=\text { Capital input }
\end{array} \\
& \quad \text { Total factor productivity }
\end{aligned}
$$

While $\alpha$ and $\beta$ are outputs of the elasticities of capital and labour respectively. The linear form of the Cobb - Douglas is:

$$
\ln (Y)=\propto_{0}+\sum_{i=1}^{n} \propto_{i} \ln \left(I_{i}\right)
$$

Where $Y=$ Output, $I_{i}=$ Inputs, and $\alpha_{i}$ are model coefficients. 
Thus, equation 3.2 can further be written as:

$$
\begin{gathered}
\ln Y=\propto_{0}+\propto_{1} \ln I_{1}+\propto_{2} \ln I_{2} \ldots \ldots \propto_{n} \ln I_{n} \\
+u
\end{gathered}
$$

Based on the work of Koss \& Lewis (1993) on Total Factor Productivity (TFP), in this study, productivity (P) was used as a proxy for output (Y) of the Cobb-Douglas production function and the input variables $\mathrm{X}_{\mathrm{i}}$ represented the factors affecting the P. As noted by Koss \& Lewis (1993), factors affecting productivity comprised of internal and external variables. The internal variables are operational factors which include labour and capital, while the external variables are the environmental factors that affect productivity for which the management could not control (Sarafidis, 2002). Hence, the internal variables (operational factors) in this study included capital (funding) and labour (manpower). Also, the external variables (environmental factors) in our study were those factors affecting productivity for which the industry has little or no control over. From our empirical review these include the level of corruption in the country, utility rates, vandals' activities, and weather conditions.

Thus, reformulating the above function and adopting the model earlier specified by Ubi et al. (2012) except for the replacement of electricity production with productivity $(\mathrm{P})$ as the endogenous variable, we have the following equation:

$\ln P$

$=a_{t}+\beta_{1} \ln L A B+\beta_{2} \ln F U N+\beta_{3} \ln P R I+\beta_{4} \ln W E A+\beta_{5} \ln C O R$

$+\beta_{6} \ln V A N$

$+\varepsilon$

Where:

$\mathrm{P}=$ Productivity

LAB $=$ Number of employee in the electricity industry

FUN $=$ Government expenditure in the electricity industry

PRI $=$ Electricity retail price $($ Tariffs $)$

WEA = Amount of rainfall in the country per year

COR $=$ Corruption Perception Index per year

VAN $=$ Vandal's activities

$\varepsilon=$ Error term

The a priori expectations of the coefficients of the explanatory variables are $\beta_{1}>0, \beta_{2}>0, \beta_{3}>0, \beta_{4}>0, \beta_{5}<0, \beta_{6}<0$.

The indicator of productivity $(\mathrm{P})$ used in this analysis is the capacity factor in the power generation which serves to measure the degree of efficiency of the electricity industry. Capacity factor is the ratio of the number of units actually generated in a given period to the number of units which could have been generated with the same maximum demand (operable capacity). 
This is an indication of the utilization of power plant capacity (ESMAP, 2009). Capacity factor is given as:

$C_{F}=\frac{C_{e a}}{C_{e i}}$

Where:

$\mathrm{CF}=$ Capacity factor,

$\mathrm{C}_{\mathrm{ea}}=$ Average energy available, and

$\mathrm{C}_{\mathrm{ei}}=$ Average energy installed

\subsection{Sources of Data}

The data for installed and actual generation capacity which provided the basis for productivity in the model were sourced from the database of United States Energy Information Administration (USEIA). The retail price of electricity (PRI) which served as the proxy for the tariff structure used in the model was obtained from the website of International Energy Commission (IEA) and the Nigerian Electricity Regulatory Commission (NERC). The Corruption Perception Index (CPI) used in this model is provided by the annual survey of Transparency International (TI) on corruption index in about 176 countries of the world. Data on government capital expenditure in the electricity industry (EXP) which served as proxy for funding were sourced from various issues of Central Bank os Nigeria (CBN) Statistical Bulletin. For information on labour and vandal's activities in the electricity industry, the data were sourced from the National Bureau of Statistics (NBS) reports. Data on the amount of rainfall per year which was used as a proxy for weather conditions were sourced from Nigerian Metrological Agency (NIMET

\subsection{Estimation Technique}

Based on study objectives, ordinary least square (OLS) technique was used to estimate the multiple regressions between productivity and factors affecting it in the electricity industry in Nigeria. To account for endogeneity, which is inherent with OLS estimations, the fully modified least square FMOLS method was used to estimate the linear regression model relating productivity in the electricity industry with its predicting variables.

\section{MODEL ESTIMATION AND INTERPRETATION}

The first point of our analysis is the examination of results from the regression equation based on the ordinary least square (OLS) model 
Table 1: The Result of the OLS Model

\begin{tabular}{|c|c|c|c|c|}
\hline Variable & Coefficient & Std. Error & t-Statistic & Prob. \\
\hline C & -0.178891 & 1.773599 & -0.100863 & 0.9212 \\
\hline LOG(LAB) & 0.190453 & 0.115040 & 1.655536 & 0.1217 \\
\hline LOG(FUN) & -0.173123 & 0.096263 & -1.798439 & 0.0954 \\
\hline LOG(PRI) & 0.142287 & 0.104903 & 1.356367 & 0.1981 \\
\hline LOG(WEA) & -0.399999 & 0.277574 & -1.441051 & 0.1732 \\
\hline LOG(COR) & 0.176126 & 0.139314 & 1.264237 & 0.2283 \\
\hline LOG(VAN) & -0.091425 & 0.040293 & -2.268982 & 0.0409 \\
\hline$R^{2}=0.63 \quad$ Adjusted R R $=0.46 \quad$ F-Stat (Prob.) $=3.75[0.000] \quad$ DW $=0.8722$ \\
\hline
\end{tabular}

Source: Author's Computation (2017) Using E-View 9.0

Table 1 above showed the results from the ordinary least square method. From this table it is observed that the $\mathrm{R}^{2}$ of .63 and its adjusted value of .43 which are the indicators of overall goodness of fit are satisfactory. However, in empirical analysis, it is not unusual to have a high $\mathrm{R}^{2}$ and yet have regression coefficients that are statistically insignificant or have signs that are contrary to a priori expectations (Gujarati, 2003). A look at table 1 above revealed that all the variables except VAL are statistically insignificant at 5\% level. This could be attributed to large standard errors as compared to the regression coefficients. Some of the coefficients like that of FUN, WEA and COR also have signs that are contrary to the specified a priori expectations. The Durbin Watson statistic of .8722 also showed evidence of auto correlation among residuals in the model.

Thus, one could observe that the method of OLS would not give results that could be used for prediction and policy formulation. One reason for this kind of results according to Green (2008) is endogeneity problem which is inherent in the OLS assumptions. Endogeneity problem in OLS often occur as a result of measurement error or the omission of a variable due to the lack of measure for it. Moyo (2012) posits that most econometric modelling of macro level determinants of productivity suffers from endogeneity problems. Thus, it should be noted that it is most unlikely that all the factors affecting productivity (the focus of our study) would be captured in one study. Also, it has been argued in the productivity and efficiency theories that the use of OLS technique is unlikely to give a satisfactory result in productivity analysis (Richmond, 1974). It was thus suggested that the corrected ordinary least square or the modified least square should be adopted as a way out of the unreasonable results that may arose from the use of the OLS technique (Gabrielsen, 1975).

Thus, in order to overcome the shortcomings noticed in the estimation with OLS in this study, we further utilised the fully modified ordinary least square (FM-OLS) method. Fully modified least square was originally designed in a work by Hansen and Phillips (1991) to provide optimal estimates 
of co-integrating regressions (Phillips, 1993). The method modifies least squares to account for serial correlation effects and for the endogeneity in the regressors that result from the existence of a co-integrating relationship. Phillips (1992) cited in Phillips (1993) posits that FM-OLS regression produces estimates of a unit root in time series regression that are hyperconsistent in the sense that their rate of convergence exceeds that of OLS estimator.

Table 2: Fully Modified Least Square

\begin{tabular}{|c|c|c|c|c|}
\hline Variable & Coefficient & Std. Error & t-Statistic & Prob. \\
\hline C & -0.527366 & 1.183226 & -0.445702 & 0.6637 \\
\hline LOG(LAB) & 0.239877 & 0.076773 & 3.124491 & 0.0088 \\
\hline LOG(FUN) & 0.182817 & 0.064916 & 2.816220 & 0.0156 \\
\hline LOG(PRI) & 0.147318 & 0.070593 & 2.086853 & 0.0589 \\
\hline LOG(WEA) & 0.449587 & 0.185382 & 2.425192 & 0.0320 \\
\hline LOG(COR) & -0.224800 & 0.116907 & -1.922893 & 0.0785 \\
\hline LOG(VAN) & -0.068608 & 0.028786 & -2.383374 & 0.0320 \\
\hline$R^{2}=0.75$ Adjusted R $\mathbf{R}^{\mathbf{2}}=0.62$ Wald test (f-test) $=8.137(0.0011)$ \\
\hline
\end{tabular}

Source: Author's Computation (2017) Using E-View 9.0

Table 2 revealed that all the variables included in the model have a significant influence on productivity (P) at the 5\% level except PRI and COR which are only significant at $5.8 \%$ and $7.8 \%$ respectively. The regression results conform to the a priori expectations. This is because the coefficients of LAB, FUN, PRI and WEA are all positives indicating direct relationships with $P$. However, the coefficients of COR and VAN are negative indicating indirect relationships with $\mathrm{P}$.

In terms of the overall performance of the model, the $\mathrm{R}^{2}$ which is an indication of the goodness of fit of the model at 0.75 is statistically significant. This means that for the period under study and based on the available data, funding, price of utility, weather condition, corruption, labour supply and vandalism jointly accounted for $75 \%$ of the total variations in the productivity in the electricity industry in Nigeria, while $25 \%$ can be said to be due to other variables that are not captured by the study. This result is further supported by the adjusted $R^{2}$ value of 0.62 is also statistically significant, which indicates that after taking into account the number of regressors, the model explains about $62 \%$ of the changes in productivity.

The F- Statistic which measures the overall goodness of fit and linearity of relationship in the model at 8.137 and its probability of 0.0011 is statistically significant. This indicates that there was a simultaneous linear relationship between the dependent variable and all the explanatory variables combined. Thus, we reject the hypothesis of a non-linear simultaneous relationship between productivity and all the explanatory variables combined. The constant term $\mathrm{C}$ at -0.527366 provides the basis for the computation of 
total factor productivity (TFP) in the model. Thus, the anti-logarithm of $\mathrm{C}$ at 0.296916 measures the total factor productivity for the productivity in the electricity industry. This is rather low if compared with international best practice of 0.80 (Akunbulire, Awosope, \& Oluseyi, 2007)).

\subsection{Test of Hypotheses}

Hypothesis One: Tariff structure does not significantly influence productivity in the electricity industry in Nigeria.

The retail price of electricity was used as proxy for the tariff structure in this study. Thus, from table 4.6, the coefficient of price of electricity (that is $\beta_{1}$ ) showed a positive sign. This therefore, conforms to the a priori expectation that there is a direct relationship between the retail price of electricity and productivity in the electricity industry in Nigeria. The t- value is 2.086853 with a probability of 0.0589 . This means that the price of electricity is only significant at $5.89 \%$. Therefore, at a test level of 5\%, we find that $\beta_{1}$ is not significantly different from zero. This shows that the price of electricity is not a good predictor of productivity at this level of analysis.

Hypothesis Two: Funding does not significantly influence productivity in the electricity industry in Nigeria.

The government annual budget for capital expenditure in the electricity sector stood as proxy for funding in this analysis. Results from FM-OLS model as shown in table 4.6 revealed that the coefficient of funding (that is $\beta_{2}$ ) is positive. This is line with the a priori expectation which states that there is a direct relationship between the level of funding and productivity in the electricity industry. The size of the parameter for funding at 0.182 measures the degree of elasticity between the level of funding and productivity. This means that a $1 \%$ change in the level of funding will induce an $18 \%$ change in the productivity.

The $t$-value for $\beta_{2}$ is 2.81660 with a probability of 0.015 . This means that funding is significant at $1.5 \%$. Thus, at a test level of $5 \%$ and $10 \%$, we find that $\beta_{2}$ is significantly different from zero. However, since our test level is $5 \%$, we reject the null hypothesis that funding does not significantly affect productivity in the electricity sector in Nigeria. The implication of this is that the level of funding has significant influence on the productivity in the electricity sector in Nigeria.

Hypothesis Three: The level of corruption does not have significant effect on productivity in the electricity sector in Nigeria.

The corruption perception index (CPI) provided by the Transparency international (TI) was used as a proxy to capture the level of corruption in the country. Results from the regression model in table 2 showed that the parameter estimate of corruption in the model (that is $\beta_{3}$ ) is negative. Thus, this conforms to the a priori expectation that the level of corruption in the 
country has an indirect relationship with productivity. The t- value for $\beta_{3}$ is 1.922893 with a probability of 0.0785 . This means that corruption as a variable in the model is only significant at $7.85 \%$ statistical level. Thus, at a test level of $5 \%$, we find that $\beta_{3}$ is not significantly different from zero. This showed that the level of corruption in the country is not a good predictor of productivity in the electricity industry in Nigeria.

Hypothesis Four: Weather condition does not significantly influence productivity in the electricity industry in Nigeria.

The amount of rainfall per year in Nigeria was used as proxy for weather condition in the country. Results from the FM-OLS model as shown in table 2 revealed that the parameter estimate of weather condition is positive. This is line with the a priori expectation that there is direct relationship between the weather condition in the country and productivity in the electricity industry in Nigeria. The $\mathrm{t}$ - value for $\beta_{4}$ is 2.423192 with a probability of 0.0320 . This means that weather condition is significant at $3.2 \%$ level. Thus, at a test level of both $5 \%$ and $10 \%$, we find that $\beta_{4}$ is significantly different from zero. However, since our test level is $5 \%$, we reject the null hypothesis that weather condition does not significantly influence productivity in the electricity industry in Nigeria.

Hypothesis Five: Vandal's activities do not significantly affect the productivity of the electricity industry in Nigeria.

The number of pipeline vandalism per year provided the basis for measuring vandalism in the country. Results from the regression model revealed that the coefficient of vandalism (that is $\beta_{5}$ ) is positive. This conforms to the a priori expectation which indicated an indirect relationship between the number of vandalism and productivity in the electricity industry in Nigeria. The $t$ - value for $\beta$ is 2.383 with a probability of 0.0345 . In essence, vandalism is significant at $3.45 \%$ test level. The broad meaning of this is that, vandalism is a good predictor of productivity in the electricity industry in Nigeria for the period under consideration.

Hypothesis six: Availability of manpower does not significantly affect productivity in the electricity industry in Nigeria.

The number of workers per year in the electricity industry in Nigeria was used as an indication for the availability of manpower. Results from FMOLS model as shown in table 2 was used to test hypothesis six. In this wise, the coefficient of labour supply (that is $\beta 6$ ) at 0.239877 is positive indicating a direct relationship between labour supply and productivity. Thus, this is line with theoretical expectation that the higher the number of workers available, the higher the level of productivity. The $t-$ value for $\beta_{6}$ is 3.124491 with a probability of 0.0088 . This means that labour supply is significant at less than $1 \%$ level. This shows that labour supply is statistically significant at $1 \%, 5 \%$ and $10 \%$ levels of significance. However, since our test level is $5 \%$, we reject 
the null hypothesis that availability of manpower does not significantly effect on productivity in the electricity industry in Nigeria.

\subsection{Discussion of Findings}

The objective of the study was to examine factors determining productivity in the electricity industry in Nigeria. Findings from the study revealed that utility rates do not have significant relationship with productivity in the electricity industry in Nigeria. This is quite surprising going by the incessant clamour for the upward review of utility rates in the Nigerian electricity industry (Isola, 2011; Iwayemi \& Adenikinju, 2001 and Subair \& Oke, 2008). The major reason for this clamour was hinged on the need to put more funds in the power utility companies to enable them to upgrade the needed infrastructure for the sector.

The test for hypothesis two of this study revealed that funding affect productivity in the electricity industry in Nigeria. In Nigeria, and until the privatisation of generation and distribution companies in 2013, government remained the largest provider of funds in the electricity sector. The study showed a direct relationship between government expenditure and productivity in the electricity industry in Nigeria. These findings agreed largely with the views of Okoro and Chikuni (2007) that adequate funding and investment in the electricity sector in Nigeria is the panacea for the various epileptic power supply being witnessed in the country. They further opined that the operators of the system if given adequate resources in terms of funding and requisite investment would be able to maintain the critical assets in the industry thereby putting an end to incessant power cuts in the country.

Hypothesis three is concerned with testing the relationship between corruption and productivity in the electricity industry in Nigeria. The test revealed that the level of corruption in the country does not significantly affect productivity in the electricity industry. This result is quite surprising judging by the amount of hue and cry in the public domain about corruption in public procurement in Nigeria. However, some authors have traced the nonsignificance of corruption in econometric models to measurement problem. For example, Heywood (2015) questions the rational of measuring a phenomenon such as corruption that is largely hidden. One major problem associated with measuring corruption is finding an appropriate index for capturing the phenomenon (Heywood, 2015).

Hypothesis four was designed to test the relationship between weather condition and productivity in the electricity industry in Nigeria. Findings from the test revealed that there is significant positive relationship between weather condition and maintenance productivity. This result is not surprising because as noted by Yusuf and Abdulaziz (2015) cited in Adegbehin, Iguisi, Yusuf, 
Zubairu and Anumonye (2016), that there is a high degree of correlation between the amount of rainfall and power generation in the electricity industry. This is particularly important because according to Usanamlele (2001), the higher the level of water in the reservoir, the more effective is the turbine and thus the less the need for maintenance of the generation segment of the hydro system.

Findings from the test of hypotheses also revealed that vandalism has an indirect relationship with productivity in the electricity industry in Nigeria. This means that the higher the level of vandalism in the country, the lower the productivity in the electricity industry. This result largely agreed with the findings of Adedokun and Osunpidan (2010) that vandalism in the electricity industry have serious implication for the maintenance efforts because it takes time to fix damaged equipment arising from vandal's activities. Vandal's activities in the electricity industry in Nigeria have posed serious challenges to operators in the sector for many years. In fact, Olugbenga, Jumah and Phillips (2013) posit that vandalism in the electricity industry in Nigeria predates the power reform era. The immediate effect of vandalism in the power sector is the long period of power outages. This is so because repairs on the vandalised equipment are not carried out on time as a result of our poor maintenance culture.

Hypothesis six was concerned with the testing of the relationship between labour supply and productivity in the electricity industry in Nigeria. Findings from the study showed that labour supply was statistically significant as a predictor of productivity in the electricity industry in Nigeria for the period of our study. Results from the test also revealed that labour supply also has a direct positive relationship with productivity. The role of effective manpower in the electricity industry cannot be overemphasised. More so when it is realised that electric utility management is dynamic and technologically driven.

The total factor productivity (TFC) which is a measure of the efficiency in the industry at 0.29 (that is 29\%) is low indicating poor management of power stations in the industry in terms of downtimes. Sambo (2005) cited in Folorunso and Olowu (2014) posits that with proper maintenance framework the productivity level in the sector has the potential of $40 \%$ performance level. However, the usual practice in most of the Nigerian electricity generation firms is to engage in reactive maintenance.

\section{Conclusion}

The power sector plays a key role in the Nigerian economy especially considering the multiple effects a stable electricity supply will have on the productive sector of the economy. This becomes more important as many manufacturing organisations are said to be relocating their plants outside the 
country. An important body of research in operations management has been to enrich existing knowledge in productivity analysis and plants performances amongst Nigeria power utilities. Even though the use of ordinary least square (OLS) technique on time series data to model productivity is considered inefficient in previous studies, however we have been able to use the modified ordinary least square (FM-OLS) in this study to achieve efficient and reliable results. This is an important contribution to the ever widening debate on the appropriate models for measuring efficiency in power utilities. The study also recommended that adequate budgetary provision be made available by government to the Nigerian electricity industry so as to improve the productivity of that sector. In addition, appropriate regulations should be put in place to ensure greater transparency in procurement in the sector in order to stem the tide of corruption in the system.

\section{References:}

1. Abbott, M. (2006). The productivity and efficiency of Australian electricity supply industry. Energy Economics, 28, 444 - 454.

2. Adedokun, G.,\& Osunpidan, I. B. (2010). Panacea to epileptic power supply in Nigeria.Pacific Journal of Science and Technology. 11(2) 164-170.

3. Adegbehin, A.B.1., Iguisi, E. O., Yusuf, I. Y. O., Zubairu, I.,\&Anumonye, E. N. (2016).Effect of weather parameters on hydroelectric power generation in Kainji Dam, Niger State, Nigeria. Paper presented at the 57th Annual Conference of the Association of Nigerian Geographers (UNILAG ANG-2016), 10th - 15th April, 2016. Lagos.

4. Ahmed, A. S. (2008). Investment implication for the projected electricity demand and supply, presented at the ECN \& NERC joint national workshop on state government participations in power sector: "Matching Supply with Demand"

5. Akunbulire, T. O., Awosope, C. O. A., \& Oluseyi, P. O. (2007). Solving the technical problems facing electrical energy development in Nigeria.3rd Annual Conference Research and Fair of the University of Lagos, Nigeria, December, 3, 175-181.

6. Ali, A.S., Kamaruzzaman, S. N., Sulaiman, R., \& Peng, Y. (2010). Factors affecting housing maintenance cost in Malaysia. Journal of Facilities Management, (8)4, 285 - 298.

7. Alli, O. A., Ogunwolu, L.,\& Oke, S. (2009). Maintenance productivity measurement: A case study of a manufacturing company. Advanced Material Research,62(1), $565-570$. 
8. Babalola, R. O. (1999). Technical efficiency and the impact of ownership on performance: The case of the Nigerian electricity industry. PhD Thesis, University of Surrey, UK.

9. Barros, C. P., Ibiwoye, A., \& Managi, S. (2011). Nigeria power sector: Analysis of productivity. University of Lisbon, working papers, WP 10/2011/DE/UECE.

10. Barzel, Y. (1963). Productivity in the electric power industry, 19291955. The Review of Economics and Statistics, 45(4), 395-408. DOI: $10.2307 / 1927924$

11. Betancourt, R. R., \& Edwards, J. H. Y. (1987). Economics of scale and the load factor in electricity generation. The Review of Economics and Statistics, 69(3), $551-556$.

12. Christtensen, L., \& Green, W. (1976). Economics of scale in the US electric power generation. Journal of Political Economy, 84, $655-$ 676.

13. Dixit, S., Chitnis, A., Wood, D., Jairaj, B., \& Martin, S. (2014). Ten questions to ask about electricity tariffs. Working Paper. Washington, D.C.: World Resources Institute. Retrieved fromhttp://www.wri.org/publication

14. Dzansi, D. Y., Rambe, P.,\& Mathe, L. (2014). Cable theft and vandalism by employees of South Africa's electricity utility companies: A theoretical explanation and research agenda. Journal of Social Science, 39(2) $179-190$.

15. Elísson, A. (2013). Performance Indicators for Maintenance in Geothermal Power Plants. ECTS thesis, School of Engineering and Natural Sciences, University of Iceland.

16. ESMAP (2009). Monitoring performance of electric utilities: Indicators and benchmarking in Sub-Saharan Africa. The energy sector management assistance program. The World Bank, Washington D.C.

17. Eti, M. C., Ogaji, S. O. T.,\& Probert, S. D. (2004). Impact of corporate culture on plant maintenance in the Nigeria electric power industry. Applied Energy, 83(4), 299-310.

18. Folorunso, O., \& Olowu,T. O. (2014). The Nigerian power system till date: A review. International Journal of Advance Foundation and Research in Science and Engineering, 1(5), 20 - 33.

19. Gabrielsen, A.(1975). On estimating efficient production functions.Working Paper noA-35, Chr. Michelsen Institute, Department of Humanities and Social Sciences, Bergen, Norway.

20. Greene, W. H. (2008). Econometric Analysis. Upper Saddle River, New Jersey: Prentice Hall. 
21. Gujarati, D. (2003). Basic econometrics. New York: The McGraw Hill Companies, Inc.

22. Gulati, M.,\& Rao, M. Y. (2006). Corruption in electricity sector. Presentation to World Bank staff, April, 2006. http://www1.worldbank.org/publicsector/

23. Gupta, R., \& Dey, S. K. (2010). Development of a productivity measurement for Tea industry. ARPN Journal of Engineering and Applied Sciences, 5(12), $16-25$.

24. Hannula, M. (2002). Total productivity measurement based on partial productivity ratios. International journal of production economics, 78 , $57-67$.

25. Hansen, B. E., \& Philips, P. C. B. (1991). Estimation and inference in models of co-integration: A simulation study. Advances in Econometrics, 8, $225-248$.

26. Heywood, P. M (2015) Measuring corruption: Perspectives, critiques and limits. University of Nottingham, UK. https://www.ceu.edu/sites/default/.../heywood

27. Ibitoye, F.,\& Adenikinju, A. (2007). Future demand for electricity in Nigeria. Applied Energy, 84, 492-504.

28. Isaac, F. O., \& Obodeh, O (2011). Performance analysis for Sapele power station; Case study for Nigeria, Journal of Engineering Trends in Engineering and Applied Science (JETEAS)2(1):166-177.

29. Isola, W. A. (2011). Market structure in the restructuring of the Nigerian electricity industry. The Journal of Energy and Development, 34(2), $74-82$.

30. Jamasb, T., \& Pollit, M. (2001). Benchmarking and regulation of electricity distribution and transmission utilities: Lessons from international experience. Cambridge: Department of Applied Economics, Cambridge University.

31. Jamasb, T., Newbery, D. M.,\& Pollit, M. G.(2004). Core indicators for determinants and performance of electricity sector in developing countries. CMI Working Papers in Economics, University of Cambridge. Retrieved fromwww.researchgate.net/ publication /4799866

32. Joseph, I. O. (2014). Issues and challenges in the privatised power sector in Nigeria. Journal of Sustainable Development Studies, 6(1), $161-174$.

33. Koss, E.,\& Lewis, D. A. (1993). Productivity or efficiency - Measuring what we really want. National Productivity Review, spring, 273 - 284.

34. Kumar, P., Varambally, K. V. M., \& Rodrigues, L. L. R. (2012). A methodology for implementing total productive maintenance in 
manufacturing industries-A case study. International Journal of Engineering Research and Development, 5(2), 32-39.

35. Lam, P. L.,\& Shiu A. (2001). A data envelopment analysis of the efficiency of China's thermal power generation. Utilities Policy, 10, $75-83$.

36. Lave, L., Ashworth, B. M., \& Gellings, C. (2007). The aging work force: Electricity industry challenges and solution. The Electricity Journal, 20(2), 71 - 78. DOI:10.1016/j.tej.2006.12.2

37. Madueme, C. C. (2002). Maintenance culture in electrical power industry in Nigeria: A case study of Afam power station, Nigeria. Journal of Technology, 21(1), $79-69$.

38. Maheshwari, V., Manwani, D. T., \& Banerjee, S. (2014). In search of a suitable productivity measurement model for Smes with special emphasis on systems approach. International Journal of Engineering and Management Research, 4(3), 200 - 207.

39. Momani, M. A. (2013).Factors affecting electricity demand in Jordan. Energy and Power Engineering, 5(1), 50-58.

40. Moyo, B. (2012). Do power cuts affect productivity? A case study of Nigerian manufacturingfirms. International Business and Economics Research Journal, 11(10), 1163 - 1174.

41. Muchiri, P. N., Pintelon, L., Martinb, H., \& De Meyer, A. (2010). Empirical analysis of maintenance performance measurement in Belgian industries. International Journal of Production Research, 48 (20), 5905-5924.

42. Nenadál, J. (2008). Process performance measurement in manufacturing organizations. International Journal of Productivity and Performance Management, 57(6), 460-467.

43. Nerlove, M. (1963). Returns to scale in electricity supply. In C. F. Christ et al. (Eds.), Measurement in economics: Studies in mathematical economics and econometrics in memory of Yehuda Grunfeld. Stanford, CA: Stanford University Press.

44. Obi, K. O.,\& Uzodigwe, A. A. (2016). An optimal assessment of electricity supply in Nigeria. Journal of Business studies Quarterly, 7(3), $110-126$.

45. Obioma, I.,\& Obioma, D. D. (2012). Empirical analysis of productivity in the Nigeria power sector. Journal of Electrical and Electronic Engineering. 3(4), $24-38$.

46. Olugbenga, T. K., Jumah, A. A., \& Phillips, D. A. (2013). The current and future challenges of electricity market in Nigeria in the face of deregulation process. African Journal of Engineering Research, 1(2), $33-39$. 
47. Okoro, V. O. (2014). Electric power industry restructuring in Nigeria. International Journal of Scientific and Technology Research, 3(4), 52 - 65.

48. Okoro, O. I.,\& Chikuni, E. (2007). Power sector reforms in Nigeria: Opportunities and challenges. Journal of Energy in Southern Africa, 18(3) 54 - 60

49. Phillips, P. C. B. (1993). Fully modified least squares and vector autoregression. Cowles Foundation Discussion Papers, no 1047.

50. Radovilsky, Z.,\& Gotcher, W. (1992). Measuring and improving productivity: A new Quantitative Approach. Productivity Improvement, May/June, 22 - 25.

51. Richmond, J. (1974). Estimating the efficiency of production . International Economic Review, 15(2) 515 -521.

52. Sink, D. (1983). Much ado about productivity: Where do we go from here? Industrial Engineering, 15(10), 36-48.

53. Steiner, F. (2001). Regulation, industry structure and performance in the electricity industry.OECD Economic Studies, 32(1), 144-174

54. Subair, K., \& Oke, D. (2008). Privatization and trends of aggregate consumption of electricity in Nigeria: An empirical analysis. African Journal of Accounting, Economics, Finance and Banking research, 3(3), $18-27$.

55. Sule, A. H. (2010). Major factors affecting electricity generation, transmission and distribution in Nigeria. International Journal of Engineering and Mathematical Intelligence, 1(3), 159-164.

56. Tallapragada, P. V. S. N. (2009). Nigeria's electricity sectorElectricity and gas pricing barriers. Journal of International Association for Energy Economics, First Quarter.

57. Tanzi, V., \& Davoodi, H. (1998). Roads to nowhere: How corruption in public investment hurts growth.International Monetary Fund Economic, 12, 1-12.

58. Tsang, A. H. C., Jardine, A. K. S., \& Kolodny, H. (1999). Measuring maintenance performance: A holistic approach. International Journal of Production Management, 19(7), 691-715.

59. Tsang, Albert H. C (2000). Maintenance Performance Management in Capital Intensive Organizations. $\mathrm{PhD}$ thesis, Department of Mechanical and Industrial Engineering, University of Toronto, 2000.

60. Ubi, P. S., Effiom, L., Okon, E. O. \& Oduneka, A. E. (2012). An Econometric analysis of the determinants of electricity supply in Nigeria. International Journal of Business Administration, 3(4), 72 82.

61. Usunamlele, O.T. (2001). Kanji and Power Supply in Nigeria. PHCN Public Relation Office: Kanji Region, Nigeria. 
62. Uzoh, A. B.,\& Duru, E. E. (2014). Power sector reform, industrial transformation and vision 20: 2020 in Nigeria: An econometric investigation. Journal of Industrial Research, 12(2), 28 - 34.

63. Wang, Y., Xie, B., Shang, L.,\& Li, W. (2013). Measures to improve the performance of China's thermal power industry in view of cost efficiency. Applied Energy, 112, 1078-1086.

64. Yu, W., Jamasb, T.,\& Pollitt, M. (2009). Does weather explain cost and quality performance? An analysis of UK electricity distribution companies. Energy Policy, 37, $4177-4188$.

65. Zubair, M. A., \& Olanrewaju, S.O. (2014). Productivity index of electricity generation and consumption in Nigeria. The International Journal of Engineering and Science, 3(5), 11 - 17 